\title{
Dormant landslides distributed in upper course of Sun Kosi Watershed and landslides induced by Nepal Gorkha Earthquake 2015
}

\author{
*Hiroshi Yagi ${ }^{1}$, Kazunari Hayashi ${ }^{2}$, Daisuke Higaki ${ }^{3}$, Ching-Ying Tsou ${ }^{3}$, and Go Sato $^{4}$ \\ ${ }^{1}$ Faculty of Education, Yamagata University, Kojirakawa, Yamagata, Japan \\ ${ }^{2}$ Okuyama Boring Co.Ltd., Yokokote, Japan \\ ${ }^{3}$ Faculty of Agriculture and Life Science, Hirosaki University, Bunkyocho, Hirosaki, Japan \\ ${ }^{4}$ Faculty of Modern Life, Teikyo-Heisei University, Nakano, Tokyo, Japan \\ *Corresponding author: yagi@e.yamagata-u.ac.jp
}

\begin{abstract}
This study detected 897 dormant landslides of deep-seated type in the upper course of the Sun Kosi Watershed. It also shows geology and slope gradient that are prone to cause deep-seated landslides in the Great Himalaya and Midland zones. The dormant landslides are predominantly distributed in geological areas of the Augen Gneiss, Benighat Slate, Robang Phyllite and the Kuncha Phyllite, considering both landslide area ratio and site number. Landslides of deep-seated type are also found prone to develop on dip-slope. Occurrence of landslides usually increases over 20 degrees of slope angle for each geological type, though the number of landslides in the phyllite area increases below 20 degrees. It is very clear that landslides in phyllite area are prone to occur from relatively lower slope angles compared to those occurring in quartzite, gneiss and the Sermathang Formation. Nepal Gorkha Earthquake 2015 caused 1804 landslides in this study area. Most of the earthquake-induced landslides are of shallow types that occurred just below break of slope, showing a shoulder shaped profile along the deep gorge. They are predominantly distributed on steep slopes in the geological areas of slate, gneiss and dolomite. None of the dormant landslides of large scale was activated by the earthquake.
\end{abstract}

Keywords: Dormant landslide, Deep-seated landslide, Augen gneiss area, Slate area, Phyllite area, Earthquake-induced landslide, Break of slope

Paper Received: 30 Jan 2018

Paper Accepted: 8 March 2018

\section{INTRODUCTION}

Landslides are one of the severest natural hazard that has to be addressed in relation to the human and social development activities. Dormant landslides of deep-seated type often rejuvenate when equilibrium of slope stability is broken by toe erosion, and ground water level change due to human activity. They sometimes evolve into catastrophe. Therefore, it is very useful to clarify which lithology, structure and slope angle are prone to cause landslide easily, from a viewpoint of avoiding landslide disasters or reduce human and economic losses.

The first step for collecting such basic data is preparation of landslide inventory maps. For example, National Research Institute for Earth Science and Disaster Resilience (NIED) has prepared "Landslide map", inventory map of dormant landslide of deep-seated type, which covers the whole territory of Japan. It is presently shown on web site superimposing on geology and topographical map in Japan and is freely provided on the site for GIS analysis. Topographic characteristics of dormant landslides were clarified (e.g. Moriwaki and Hattanji, 2002; Fujiwara et al., 2004). Dormant landsides were sometimes rejuvenated by breaks of equilibrium of slope stability due to heavy rain, earthquake or human activity such as removal of toe part of the landslide due to road cutting. Based on such empirical rule, landslide hazard mapping for deep-seated landslide was also carried out for Pokhara-Baglung road in Nepal (DPTC,1998). The author has carried out landslide mapping in Nepal since 1993 (Yagi and Oi, 1993; Yagi and Tezuka, 1999; Yagi, 2015). Those study clarified that landslide occupancy ratio is relatively low in granite, quartzite and limestone zones of the Kathmandu Group, and that it is generally high in metasediment zones such as phyllite, slate and phyllitic schist of the Midland Group. They also showed that landslides had occurred predominantly on dip-slope in most of geological zone, especially in meta-sediment zone of the Midland Group.

This study documents the geology and slope angle of the dormant landslides that are prone to cause deep-seated landslides both in the Great Himalaya and the Midland zones. It also tries to clarify characteristics of earthquake induced landslides such as type, geology and geomorphology.

\section{STUDY AREA}

The authors made inventory mapping in the upper course of the Sun Kosi Watershed including the Melamchi River, Indrawati Nadi, Balephi Khola and the Bhote Kosi River in Nuwakot and Sindhupalanchok districts, northeastward from 


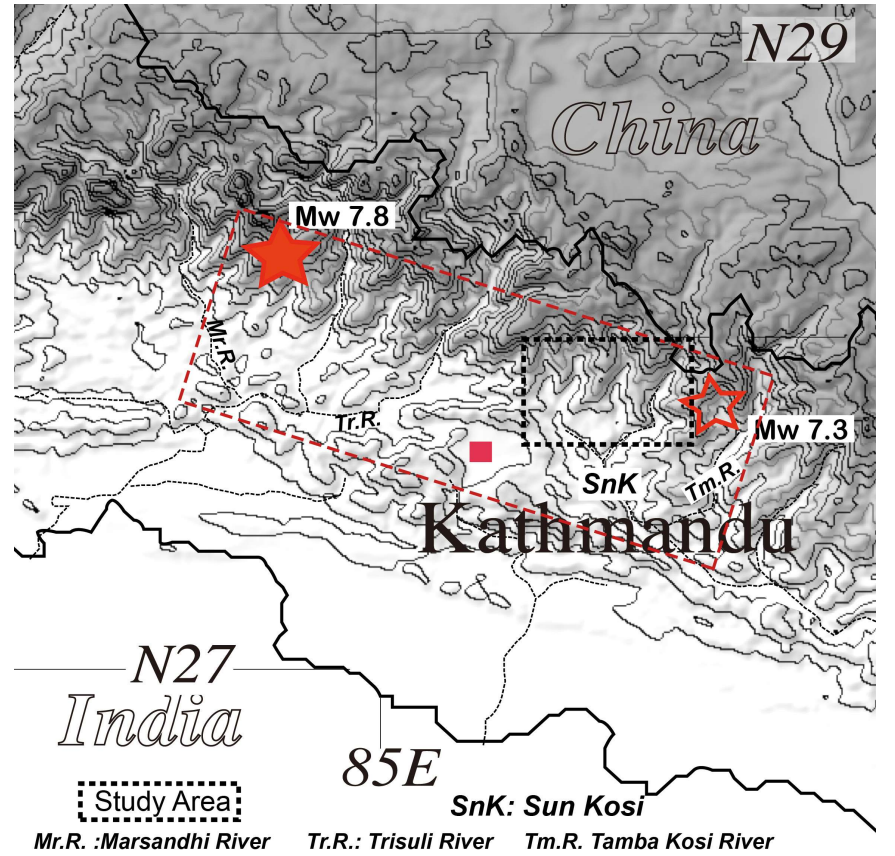

Fig. 1: Study area and topographic outline of Nepal Himalayan region. The two stars locate the epicenters of the M7.8 April the 25th 2015 Gorkha earthquake and the 12 may M7.3 Kodari Earthquake. The large light dashed rectangle delineates the approximate area of the MHT ruptured during the Gorkha earthquake and following aftershocks.

the Kathmandu Valley, central Nepal (Fig. 1). This area is located in a topographic transitional zone from the Lesser Himalaya to the Great Himalaya behind Kathmandu. Elevation of terrain ranges from 700 to $4500 \mathrm{~m}$ a.s.1.

The study area is underlain mainly by metasediments and partially by limestone and dolomite in the Middland Zone and is underlain by the Central Crystallines in a mount foot area of the Great Himalaya. These topographic zones are bordered by the Main Central Thrust (MCT). It is also located just above the source fault "Mega Thrust" that caused Nepal Gorkha Earthquake 2015 (Fig. 1). The study area was also severely affected by it which induced much slope rupture in this mountainous area (e.g. Kargel et al., 2016; Lacroix, 2016; Tsou et al., 2017).

\section{STUDY METHOD}

Eight hundred and ninety seven dormant landslides, landslide landforms of deep-seated type which consist of horse shoe shaped main scarp and ragged terrain composed of depositional part of debris, were detected by 3D aerial-photo interpretation. Scale of aerial-photos is $1 / 50,000$. They were taken by Department of Survey in early 1990's. Topographic maps that the authors used in this study are also issued from it. The study area covers the grid area of topographic maps of 2785- 03 \& 04 issued from the Survey Department. It coincides with the geographic area between $27.75000 \mathrm{~N}$ to $28.00000 \mathrm{~N}$ and $85.75000 \mathrm{E}$ to $86.0000 \mathrm{E}$. All dormant landslides were digitized as polygon data.

They also used ALOS DEM of 30 meters grid size issued from JAXA for topographic analysis by GIS. Geological maps that the authors referred are Melamchi and Barahabise areas in a scale of 1/50,000 (DMG, 2005). Each geological area was also digitized as polygon data.

Furthermore, distribution of the landslides that Nepal Gorkha earthquake induced landslides in 2015 were detected by satellite images of Google Earth taken after the earthquake for the same area of the dormant landslide study. The total number of the earthquake-induced landslides is 1804 in the Barabise area along the Bhote Kosi River, however, most of them are shallow and smaller ones less than 0.05 ha in source area. The authors digitized the top part of them as point data for GIS analysis. Those two landslide inventory maps; as to dormant landslides and earthquake induced landslides are superimposed on geological and topographic maps (Fig. 2).

To clarify relationship between dormant landslides and geology, geology type (rock types with structure) of a source area was checked for each landslide. Landslide area ratio for each geology type was calculated using ALOS DEM (Table 1). Then the authors checked slope angle of a source area (Fig. 3) for all 897 landslide sites distributed in the study area and sorted them for each geology type (Fig. 4). Landslide frequency versus slope angle of the source area, equivalent friction angle, is shown as a diagram for each geology type (Fig. 4). It also shows cumulative occurrence ratio of landslide for each geology type.

The geology was also checked at every earthquakeinduced landslide. And then number of landslide site and landslide frequency per $1 \mathrm{sq}$. $\mathrm{km}$ by each geology type is shown in Fig. 5. Mean slope angle of earthquake induced landslide site for each geology type is also shown in Table 2.

\section{RESULT}

Dormant landslides of the deep-seated type are distributed in an area below 3,500 $\mathrm{m}$ a.s.1. The authors think that the load on mountain slope as a driving force to cause landslide was eroded by the valley glacier in the former Ice Age above that level. As to geology, they are predominantly distributed in geological areas of the Augen Gneiss, Robang Phyllite, Benighat Slate and the Kuncha Phyllite, considering that they occupy the positions of top 3 in the items of area ratio or the number of the landslide site, respectively (Table 1). Scale of dormant landslide also becomes larger in the areas of limestone, though its number is only 14. Eastern adjoining area of this study area along the Tamba Kosi River also showed that landslides are dominant in phyllite and augen gneiss areas (Yagi and Tezuka, 1999).

Most of large landslides are sliding down to northwest, reflecting the geological structure that declines to northwest 


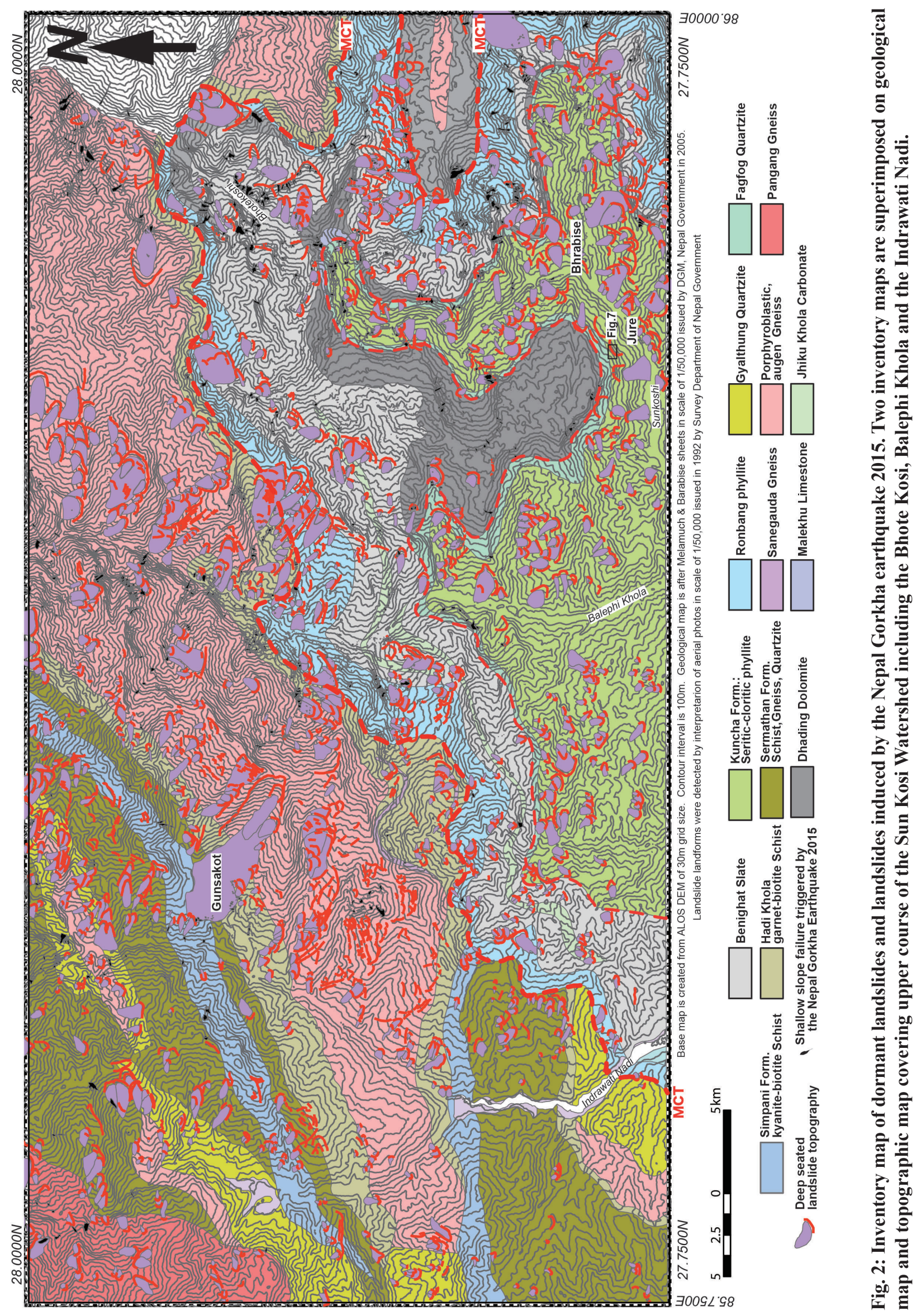


Table 1: Specification of landslide occurrence in each geological area

\begin{tabular}{|c|c|c|c|c|c|}
\hline Geology & Area (ha) & Landslide area (ha) & Landslide area ratio $(\%)$ & Site number & Area/site (ha) \\
\hline Augen Gneiss & 33275.99 & 4894.95 & 14.71 & 170 & 28.79 \\
\hline Pangan Gneiss & 3915.20 & 433.45 & 11.07 & 31 & 13.98 \\
\hline Benighat Slate & 15995.27 & 1853.70 & 11.59 & 105 & 17.65 \\
\hline Malekhu Limestone & 2435.00 & 796.83 & 32.72 & 14 & 56.92 \\
\hline Dhading Dolomite & 5568.96 & 468.30 & 8.41 & 25 & 18.73 \\
\hline Fagfog Quartzite & 2280.70 & 290.00 & 12.72 & 16 & 18.13 \\
\hline Gyalthung Quartzite & 5654.21 & 577.44 & 10.21 & 46 & 12.55 \\
\hline Sanegauda Quartzite & 154.77 & 0.00 & 0.00 & 0 & 0.00 \\
\hline Kuncha Phyllite & 19205.77 & 3016.66 & 15.71 & 185 & 16.31 \\
\hline Robang Phyllite & 11214.23 & 2359.00 & 21.04 & 85 & 27.75 \\
\hline Nourpul pinkish Phyllite & 107.60 & 0.00 & 0.00 & 0 & 0.00 \\
\hline Grey Phyllite with carbonate band & 1006.12 & 94.10 & 9.35 & 11 & 8.55 \\
\hline Garnet-biotite Hadi khola Schist & 10209.96 & 1061.10 & 10.39 & 81 & 13.10 \\
\hline Simpani Kyanite-biotite-feldspar Schist & 4727.52 & 235.75 & 4.99 & 27 & 8.73 \\
\hline Sermathang Schist with Gneiss Quartzite & 17112.18 & 1469.54 & 8.59 & 101 & 14.55 \\
\hline
\end{tabular}

concordant to the trend of the MCT. Consequently, landslides of deep-seated type are also prone to develop on dip-slope in this area. Landslides usually occur easier on dip slope than on anti-dip slope under the same geological condition.

The biggest dormant landslide of deep-seated type is greater than 10 square kilometers area. It is located at Gunsakot in the augen gneiss area and in the watershed of the Indrawati

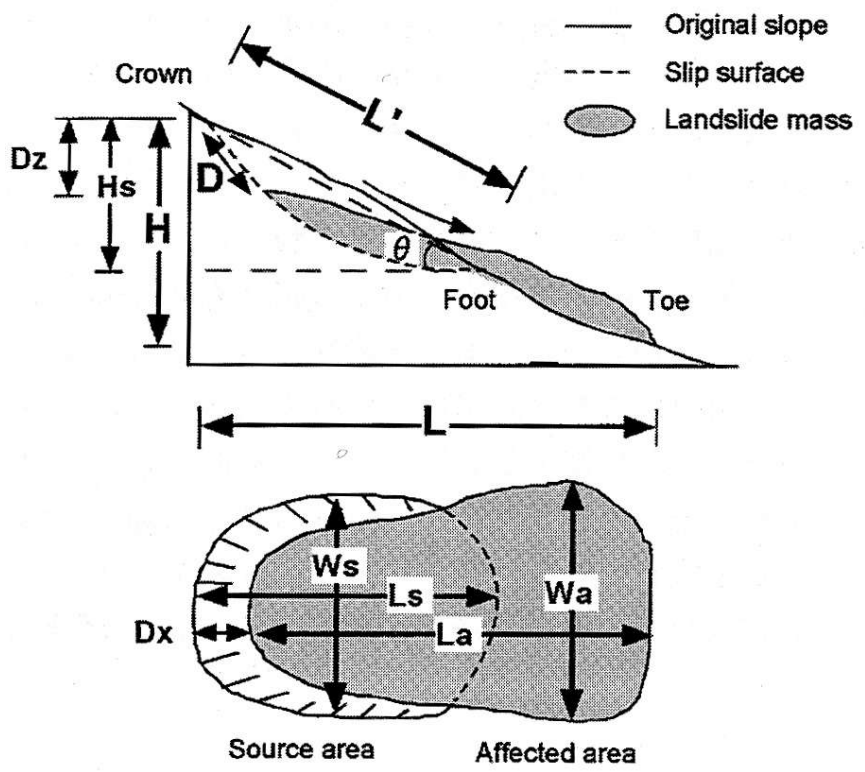

Fig. 3: Schematic geometry of a deep seated landslide and parameters. After Moriwaki and Hattanji (2002): Slope angle of source area $=\mathrm{Hs} / \mathrm{Ls}$
River. Gravitational deformation also has proceeded in the augen gneiss area, forming multiple ridges widely along the top ridge and uphill facing scarplets and linear depressions on its surrounding slope in the southern part of Gunsakot. This implies that more mega-scale landslide will occur in future, but its timing is unclear.

Large-scale dormant landslides down to northwest are also seen in the Robang Phyllite area locating in the footwall side of the MCT. However, landslides located along the gorge of the Bhote Kosi-Sun Kosi valley sometimes develop on antidip slope or intermediate slope between dip and anti-dip slopes. This implies that rapid incision along a transverse river as the Bhote Kosi-Sun Kosi crossing the Great Himalaya has formed steep valley slope and has caused many landslides.

Landslide initiates to occur at slope angle between 10 and 15 degrees as shown in Fig. 4. Occurrence of landslide usually increases over 20 degrees of slope angle for each geological type, though the number of landslide in phyllite area rapidly increases below 20 degrees (Fig. 4). Slope angle at which the cumulative occurrence ratio becomes over $20 \%$ is 22 degrees for quartzite and is 19 degrees for phyllite. Mean slope angle of quartzite, gneiss, the Sermathang Formation (alternate of schist, gneiss and quartzite), schist, slate and phyllite are 27.0, 26.4, 25.8, 25.2, 24.9 and 24.4 degrees, respectively (Fig. 4). It is very clear that landslide in phyllite area is prone to occur from relatively lower slope angle of both mean and mode compared with those in quartzite, gneiss and the Sermathang Formation areas. Gneiss area shows relatively high frequency at higher slope angle. Gneiss area is located in the Great Himalaya zone of high relief. Planer dimension of landslide in the augen gneiss area is the widest in those of all geological 

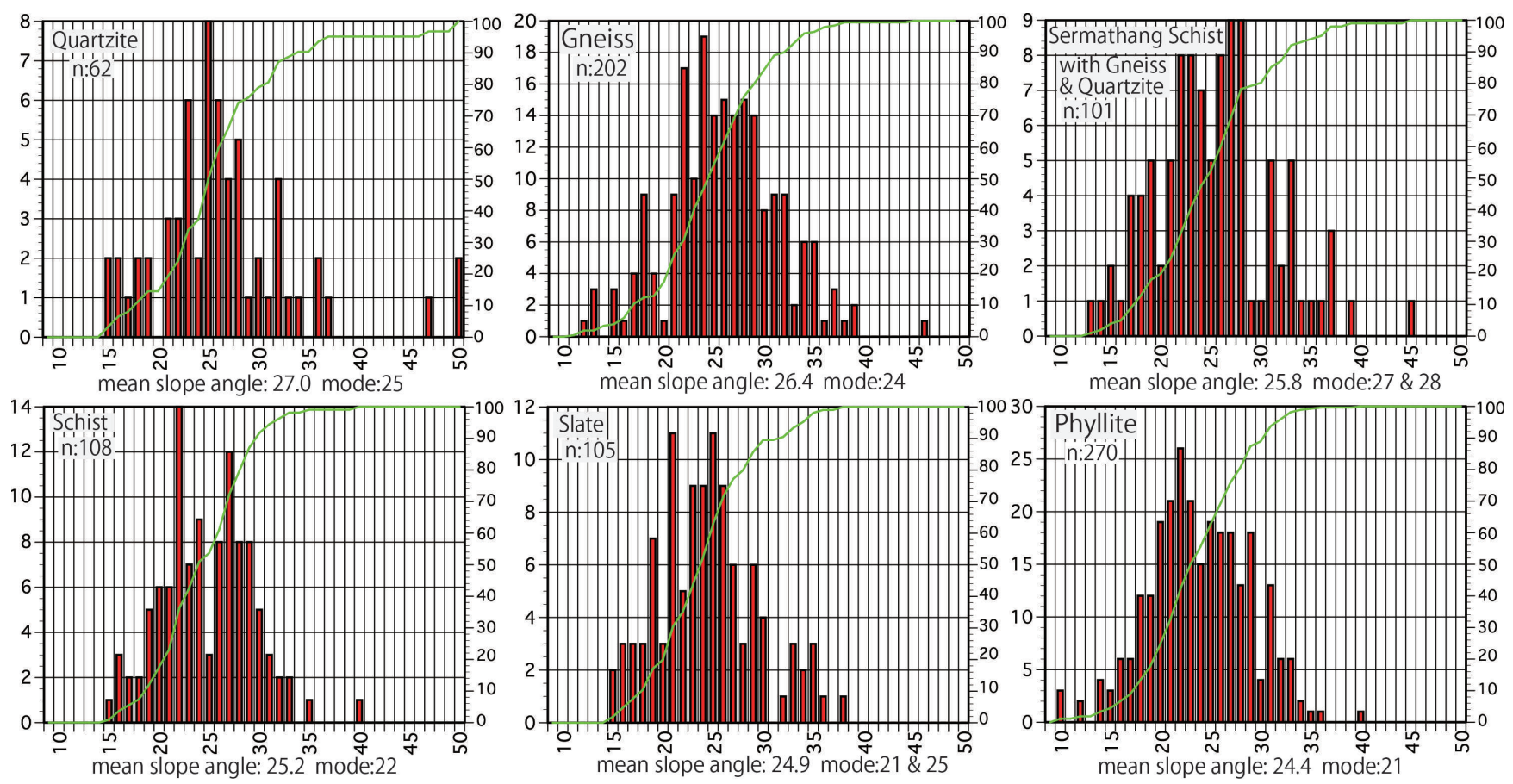

Fig. 4: Diagrams showing frequency of landslide versus slope angle for each geology type. All gneissose, schistose, phyllitic and quartzite rock groups are united for convenience, respectively. Line chart is a cumulative occurrence ratio of landslide for each geology type.

type, too. Those imply that the augen gneiss has high resistance for landslide, however, it sometimes causes a large-scale landslide in high relief areas of the Great Himalaya.

Numerous landslides were induced by the Gorkha Earthquake 2015 in mountain slopes just above the fault plane ruptured by the Nepal Gorkha Earthquake 2015. Most of them are shallow landslides which occurred just below break of slope, showing a shoulder shaped profile along the deep gorge (Figs. 2 and 6). Mean slope angle of the earthquake-induced landslide site for each geology type ranges from 37 to 40.6 degrees (Table 2 ). Strong ground motion was presumably amplified by the topographic effect of the shoulder shaped profile and caused shallow landslides (Meunier et al., 2008; Wakai et al., 2017). They are concentrated in the geological areas of slate, gneiss and dolomite (Fig. 5). The number of landslides in the quartzite area is small, however, landslide's number per one square kilometer is the highest. This simply depends on that area dimension of quartzite is quite narrow (Table 1). The phyllite area shows relatively lower occurrence number of earthquakeinduced landslides except along the gorge of the Sun Kosi and the Bhote Kosi Rivers. It is presumably attributed to that most of phyllitic rock is underlain in the Midland side where relief is relatively low.

There are many dormant landslides distributed in the earthquake affected region as mentioned above. However, reactivation of the dormant landslide of the deep-seated type is not observed even in the large landslide at Jure-Barabise occurred in 2014 (Fig. 7). That is a matter to be considered. The authors are preparing to report about that in another paper in near future.

\section{CONCLUSIONS}

As to geology that is prone to cause deep-seated landslides in topographic zones of the Great Himalaya and the Midland, geological areas of the Robang Phyllite and the Kuncha Phyllite showed high area ratio and high number of the landslide site. Landslides of deep-seated type are also prone to develop on dip-slope. Occurrence of landslide usually increases over 20 degrees of slope angles for each geological type except phyllite. It is very clear that landslide in the phyllite area is prone to occur from relatively lower slope angles of both mean and mode

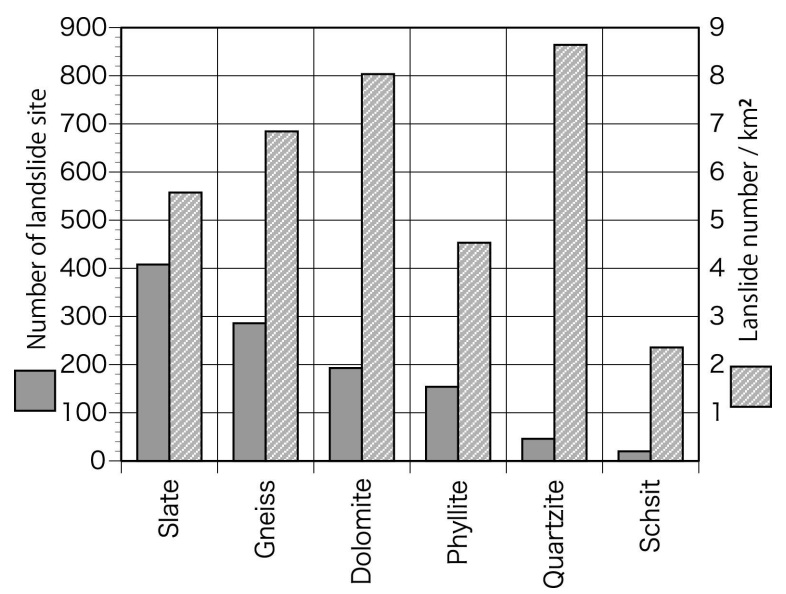

Fig. 5: Total number of earthquake induce landslide site for each geology type and landslide number $/ \mathrm{km}^{2}$ 


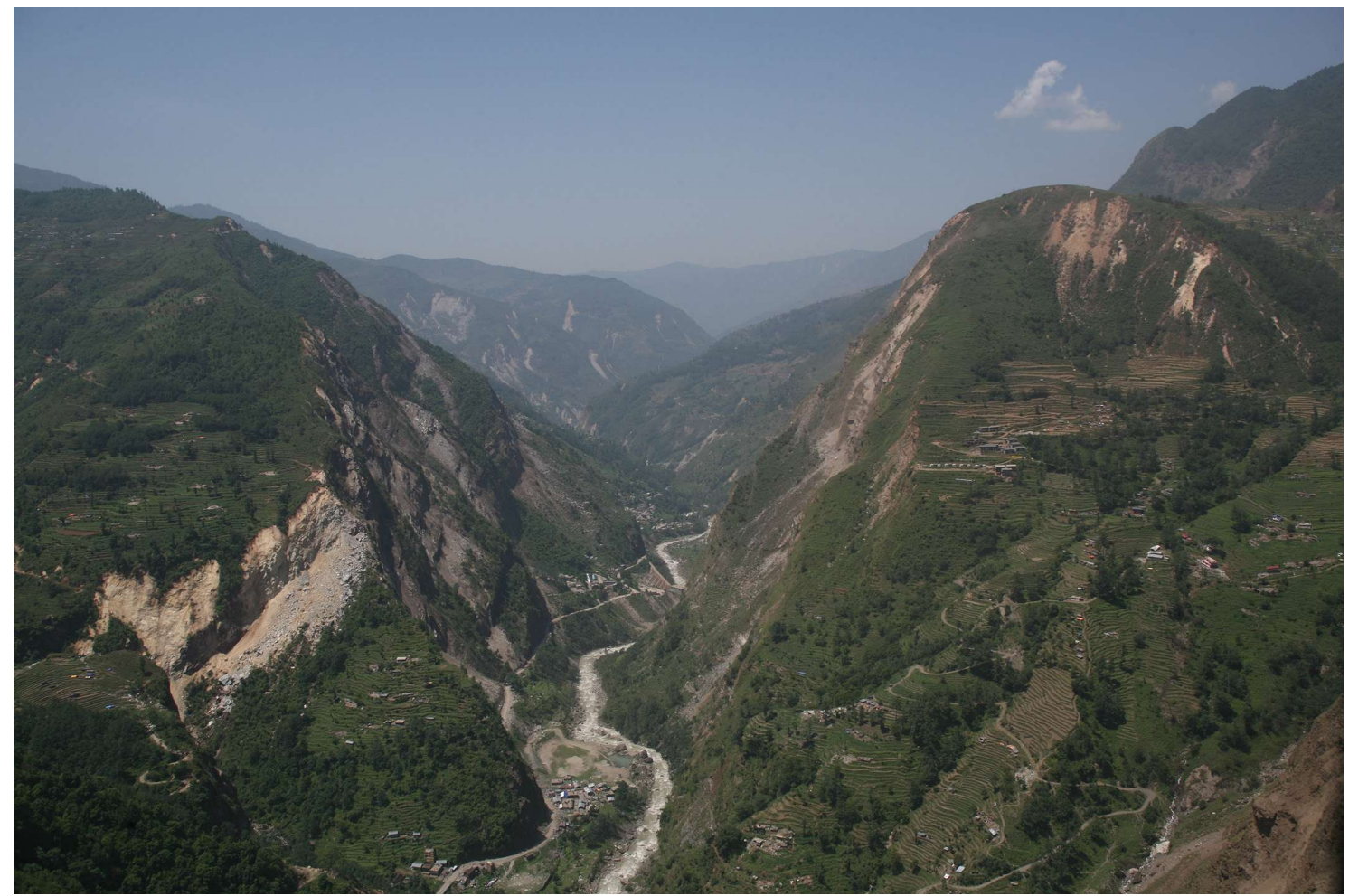

Fig. 6: Shallow landslide triggered by the Nepal Gorkha Earthquake 2015 along the Bhote Kosi Gorge

Table 2: Mean slope angle of earthquake induced landslide site for each geology type

\begin{tabular}{cccccccc}
\hline Geology & Slate & Gneiss & Dolomite & Phyllite & Quartzite & Limestone & Schist \\
\hline Mean slope angle & 37.0 & 38.7 & 37.2 & 37.6 & 38.5 & 40.6 & 38.5 \\
\hline
\end{tabular}

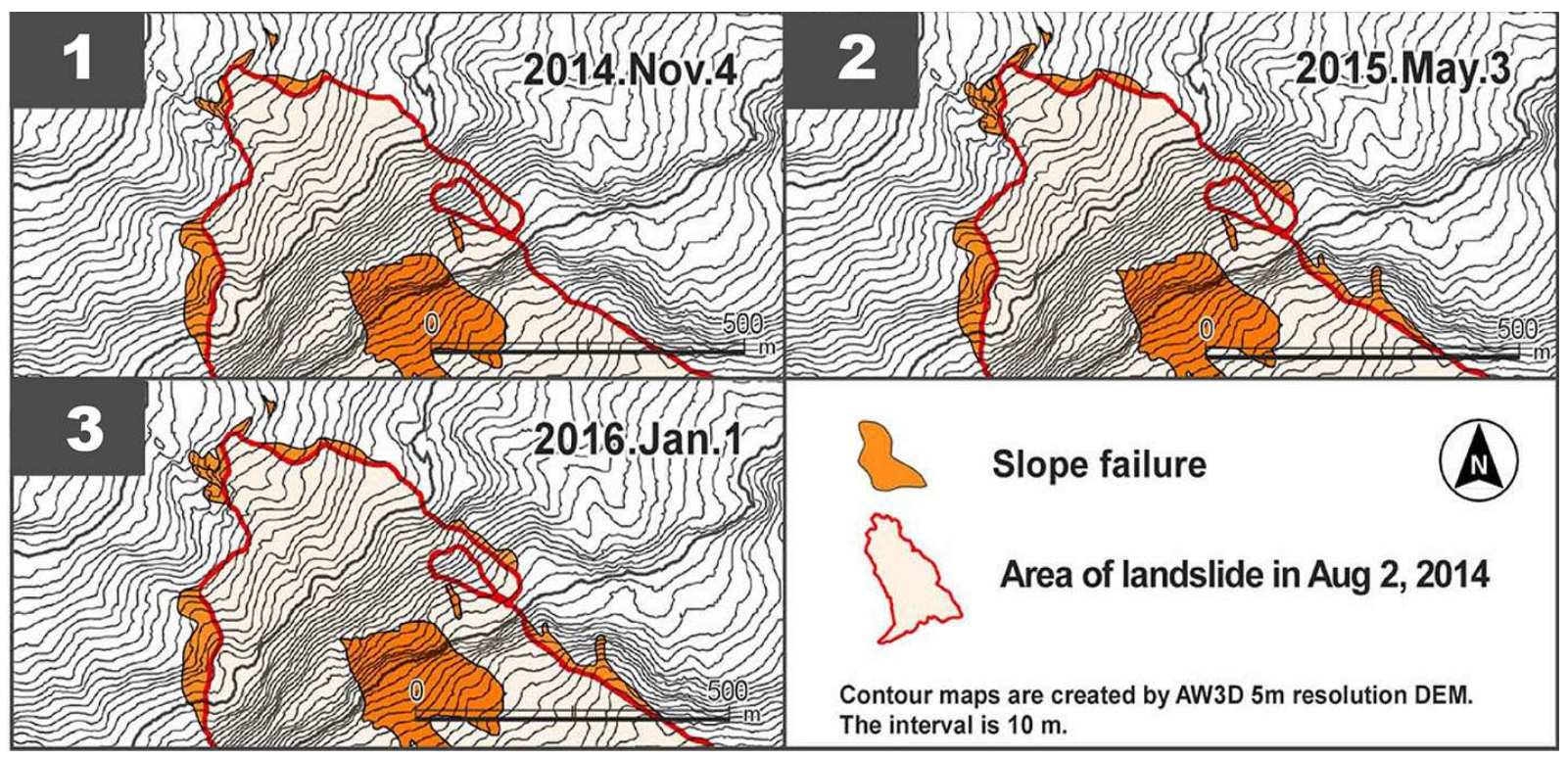

Fig. 7: Retrogressive change of the crown due to the Nepal Gorkha earthquake in Jure-Barabise landslide occurred in 2014. Three phases of Google satellite images taken in 4th Nov.2014, 3rd May 2015 \& 1 st Jan. 2016 were compared. Red solid line is outline of the Jure-Barabise landslide that occurred in Aug. 2014. 
compared with those in the quartzite, gneiss and the Sermathang Formation areas.

Most of landslides induced by the Gorkha Earthquake 2015 are of shallow types that occurred just below break of slope, showing a shoulder shaped profile along the deep gorge. They are predominantly distributed in the geological areas of slate, gneiss and dolomite. However, any dormant landslides of deep-seated type were not activated by the earthquake in 2015.

\section{ACKNOWLEGEMENTS}

The authors deeply appreciate Emeritus Prof. Dr. Vishnu Dangol of Tri-chandra Campus, Tribhuvan University for his long and sincere support to this research work in Nepal, including aerial photo interpretation at Department of Survey and field study trips. They also thank Mr. S. K. Bhattachan and Dawa T. Sherpa for their support in the field sites. This work was supported by JSPS KAKENHI Grant Numbers JP16K01211,16H0314901.

\section{REFERENCES}

DMG, 2005, Geological map of part of Sindhupalchok and Nuwakot Districts (Melamchi area) 1/50,000. Department of Geology and Mines, Nepal Government, Lainchaur, Kathmandu, Nepal.

DMG, 2005, Geological map of part of Sindhupalchok District (Barhabise area) 1/50,000. Department of Geology and Mines, Nepal Government, Lainchaur, Kathmandu, Nepal.

Hujiwara, O., Yanagida. M., Shimizu, N. Sanga, T., and Sasaki, T., 2004, Regional distribution of large landslide landforms in Japan -implication in geology and landform-. Jour. Japan Landslide Society, v. 41, no.4, pp. 335-344.

Kargel, J. S., Leonard, G. J., Shugar, D. H., Haritashya, U. K., Bevington, A., Fielding, E. J., Fujita, K., Geertsema, M. Miles, E. S., Steiner, J., Anderson, E., Bajracharya, G. W., Bawden, G. W., Breashears, D. F., Byers, A., Collins, B., Dhiral, M. R., Donnellan, A., Evans, T. L., Geai,M. L., Glasscoe, M.T., Green, D., Gurung, D, R., Heijenk, R., Hilborn, A., Hundnut, K., Huyck, C., Immerzeel, W. W.,Jiang Kiming, Jibsin, R., Kaab, A., Khanal, N.R., Kirschbaum, D., Kraaijenbrink, P. D. A., Lamsal, D., Liu Shiyin, Lv.Mingyang, McKinney, D., Nahirnick, N.K., Nan Zhuotong, Ojha,S., Olsenholler, J., Painter, T. H., Pleasants, M., Pratima, K. C., Yuan, Q. I., Raup,B. H., Regmi, D., Rounce, D. R., Sakai, A., Shangguan Donghui, Shea, J. M., Shrestha, A.B., Shukla, A., Stumm, D., vander Kooji, Voss, K., Wang Xin, Weihs, B., Wolfe, D., Wu Lizzong, Yao Xiaojun, Yoder, M. R., and Young, N., 2016, Geomorphic and geologic controls of geohazards induced by Neapl's 2015 Gorkha earthquake. Science, vol. 351 no. 6269, aac8353-1-10. DOI:10.1126/science.aac8353.

Lacroix, P., 2016, Landslides triggered by the Gorkha earthquake in the Langtang valley, volumes and initiation processes. Earth, Planets and Space. 68: 46, DOI10.1186/s40623016-0423-3.

Meunier. P., Hovius, N., and Haines, J.A., 2008, Topographic site effects and the location of earthquake induced landslides. Earth and Planetary Science Letters, 275 (34), pp. 221-232.

Ministry of Irrigation, 2014, Report on Jure landslide, Mankha VDC, Sindhupalchok District. Nepal Government, 29 p.

Moriwaki, H. and Hattanji, T., 2002, Morphometric analysis of landslides based on landslide map. Jour. Japan Landslide Society, v.39, 2, pp. 244-252. (in Japanese)

NIED Home page, Landslide landform data base.

Tsou, C.Y., Chigira, M., Higaki, D., Sato, G. YAGI, H., Sato, P.H., Wakai, A., Dangol, V., Amatya, S.C., and Yatagai, A., 2017, Topographic and geologic controls on landslides induced by the 2015 Gorkha earthquake and its aftershoks: an example from the Trishuli Valley, central Nepal. Landslides, Journal of the International Consortium on Landslides. pp.1-13, https://doi.org/10.1007/s10346-0170913-9

Yagi, H. and Oi, H., 1993, Hazard mapping on large scale landslides in Lower Nepal Himalayas. Landslides, Novosad, S. and Wagner, P. (eds) Proceedings of 7th International conference and field workshop, Balkema, pp.11-116.

Yagi, H. and Tezuka, H., 1999, Landslide distribution in the mid-eastern part of the Lowe Nepal Himalayas with special reference to geology and geomorphology. Jour. Nepal Geological Society, v. 20, Special Issue, pp. 228-229.

Yagi, H., 2015, Critical slope angle inducing landslides on dip slope by each geological type in central western part of the Lower Nepal Himalayas. Jour. Nepal Geological Society, 48, Abstract volume of 7 th Nepal Geological Congress (NGC-VII), $52 \mathrm{p}$.

Wakai A., Higaki D., Yagi H., Sato G., Chigira M. 2017, Finite element simulation for seismic ground response in mountainous areas in Nepal. In: Mikoš, M., Casagli, N., Yin Y., Sassa, K. (eds) Advancing Culture of Living with Landslides. Springer, Cham, pp. 67-74.

Water Induced Disaster Prevention Technical Centre, 1998, Primary guideline for landslide hazard mapping. Ministry of Water Resources, HMG Nepal, the Appendix map of four sheets, $28 \mathrm{p}$. 
